\title{
Antifibrotic effect of lung-resident progenitor cells with high aldehyde dehydrogenase activity
}

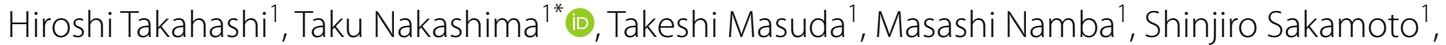 \\ Kakuhiro Yamaguchi', Yasushi Horimasu', Shintaro Miyamoto' ', Hiroshi Iwamoto', Kazunori Fujitaka', \\ Hironobu Hamada ${ }^{2}$ and Noboru Hattori ${ }^{1}$
}

\begin{abstract}
Background: Aldehyde dehydrogenase (ALDH) is highly expressed in stem/progenitor cells in various tissues, and cell populations with high ALDH activity $\left(\mathrm{ALDH}^{\mathrm{br}}\right.$ ) are associated with tissue repair. However, little is known about lung-resident $\mathrm{ALDH}^{\mathrm{br}}$. This study was performed to clarify the characteristics of lung-resident $\mathrm{ALDH}{ }^{\mathrm{br}}$ cells and to evaluate their possible use as a tool for cell therapy using a mouse model of bleomycin-induced pulmonary fibrosis.

Methods: The characteristics of lung-resident/nonhematopoietic $\left(\mathrm{CD}^{-} 5^{-}\right) \mathrm{ALDH}^{\text {br }}$ cells were assessed in control $\mathrm{C} 57 \mathrm{BL} / 6$ mice. The kinetics and the potential usage of $\mathrm{CD} 45^{-} / \mathrm{ALDH}^{\mathrm{br}}$ for cell therapy were investigated in bleomycininduced pulmonary fibrosis. Localization of transferred CD45-/ALDH ${ }^{\text {br }}$ cells was determined using mCherry-expressing mice as donors. The effects of aging on ALDH expression were also assessed using aged mice.

Results: Lung $\mathrm{CD} 45^{-} / \mathrm{ALDH}^{\mathrm{br}}$ showed higher proliferative and colony-forming potential than cell populations with Iow ALDH activity. The CD45-/ALDH ${ }^{\text {br }}$ cell population, and especially its CD45-/ALDH ${ }^{\text {br }} / \mathrm{PDGFRa}^{+}$subpopulation, was significantly reduced in the lung during bleomycin-induced pulmonary fibrosis. Furthermore, mRNA expression of ALDH isoforms was significantly reduced in the fibrotic lung. When transferred in vivo into bleomycin-pretreated mice, $C D 45^{-} / \mathrm{ALDH}^{\mathrm{br}}$ cells reached the site of injury, ameliorated pulmonary fibrosis, recovered the reduced expression of ALDH mRNA, and prolonged survival, which was associated with the upregulation of the retinol-metabolizing pathway and the suppression of profibrotic cytokines. The reduction in CD45-/ALDH ${ }^{\mathrm{br}} / \mathrm{PDGFRa}^{+}$population was more remarkable in aged mice than in young mice.

Conclusions: Our results strongly suggest that the lung expression of ALDH and lung-resident CD45- $/ \mathrm{ALDH}^{\mathrm{br}}$ cells are involved in pulmonary fibrosis. The current study signified the possibility that $\mathrm{CD} 45^{-} / \mathrm{ALDH}^{\mathrm{br}}$ cells could find application as novel and useful cell therapy tools in pulmonary fibrosis treatment.
\end{abstract}

Keywords: Aldehyde dehydrogenase, Bleomycin, Cell therapy, Profibrotic cytokines, Pulmonary fibrosis, Stem cells

*Correspondence: tnaka@hiroshima-u.ac.jp

${ }^{1}$ Department of Molecular and Internal Medicine, Graduate School of Biomedical and Health Sciences, Hiroshima University, 1-2-3 Kasumi, Minami-ku, Hiroshima 734-8551, Japan

Full list of author information is available at the end of the article

\section{Background}

Tissue-resident stem cells are valuable in cell therapy and have been successfully used for immunomodulation, tissue regeneration, and tissue repair. Several trials using stem cell therapy have been performed to treat refractory diseases, with mesenchymal stem cells (MSCs) being the most frequently used cell type [1]. In particular, MSCs, 
shown to exhibit pluripotency toward the nonhematopoietic cell lineage, can be isolated from various organs, including the bone marrow, adipose tissue, skeletal muscle, and the umbilical cord [1]. Bone marrow-derived MSCs, isolated from the most orthodox cell source of MSCs [2, 3], have been shown to have immunomodulatory effects such as the inhibition of the proliferation of T-cells through secretion of anti-inflammatory cytokines and growth factors [4]. In a mouse model of bleomycin (BLM)-induced lung injury, administration of bone marrow-derived MSCs was reported to improve lung injury by exerting an anti-inflammatory effect [5]. With respect to lung resident stem cells, the $\mathrm{Sca} 1^{+} / \mathrm{CD} 45^{-} / \mathrm{CD} 31^{-}$cell population has been identified as lung tissue stem cells capable of differentiating into endothelial and lung epithelial cells in vitro. Moreover, when transferred into an elastase-induced lung injury mouse model, this population was demonstrated to significantly improve the survival rate and reverse lung damage [6]. Lung Hoechst $33342^{\text {dim }}$ side population (SP) cells are adult stem cells, which have also been identified to exhibit mesenchymal and epithelial potential [7]. Among the SP cells, the $\mathrm{CD} 45^{-} / \mathrm{CD}^{-} 1^{-}$fraction has been reported to have the characteristics of lung resident MSCs, due to their ability to differentiate into smooth muscle, bone, fat, and cartilage $[8,9]$. Furthermore, the number of lung resident SP cells was shown to be significantly reduced in mice with BLM-induced lung injury, and this reduction was correlated with the pathology of the lung injury. When administered intravenously into the lung, lung SP cell therapy was shown to reduce BLM-induced pulmonary fibrosis and pulmonary arterial hypertension [10]. These results suggest the existence of tissue-specific MSCs in the lung and their involvement in lung injury.

Aldehyde dehydrogenases (ALDH) are a group of enzymes that catalyze the oxidation of aldehydes to carboxylic acids, with 19 different isoforms in humans [11]. A cell population with high ALDH activity, called ALDH bright cells $\left(\mathrm{ALDH}^{\mathrm{br}}\right)$, is associated with the stemness of various normal tissues and is involved in tissue repair [12]. Moreover, $\mathrm{ALDH}^{\mathrm{br}}$ isolated from the human bone marrow, reported to have a higher colony-forming capacity when compared to a cell population with low ALDH activity $\left(\mathrm{ALDH}^{\mathrm{dim}}\right)$ [13], was shown to be a progenitor population for epithelial, endothelial, and mesenchymal lineages [14]. When administered in a mouse model of myocardial infarction, $\mathrm{ALDH}^{\mathrm{br}}$ collected from the human umbilical cord blood was demonstrated to enhance angiogenesis in the ischemic heart [15]. Given these findings, the existence of lung resident ALDH $^{\text {br }}$ and its contribution to tissue repair were speculated; however, little is known about lung resident ALDH ${ }^{\text {br }}$. The objectives of this study were to clarify the characteristics of lung-resident $\mathrm{ALDH}^{\mathrm{br}}$ and to evaluate its possible use as a tool for cell therapy in a mouse model of BLM-induced pulmonary fibrosis.

\section{Methods}

Animals and BLM-induced pulmonary fibrosis

This study, aimed at elucidating the characteristics of lung-resident $\mathrm{ALDH}^{\mathrm{br}}$ and exploring its usage in cell therapy, was performed in accordance with the protocols approved by the Animal Ethics Committee of Hiroshima University (A19-122 and 28-29-2). In this study, pulmonary fibrosis was induced as previously described [16] in C57BL/6J mice (6-8-week-old young female mice and 52 week old aged female mice) which were purchased from Charles River Laboratories Japan (Yokohama, Japan). The mice were maintained in a specific pathogen-free environment and randomly assigned to BLM or control groups. In experiments performed to confirm the localization of transferred cells, C57BL/6Gt (ROSA)26Sor $<$ tm1.1 (H2B-mcherry) Osb $>$ heterozygotic mice (mCherry mouse, BRC No. RBRC06036, RIKEN, Tokyo, Japan) [17] systemically expressing the mCherry protein in their nuclei were used as a donor population. On day 0 , after intraperitoneal injection of mixed anesthesia with medetomidine hydrochloride ( $0.3 \mathrm{mg} / \mathrm{kg}$ body weight; Kyoritsu Seiyaku, Tokyo, Japan), midazolam ( $4 \mathrm{mg} / \mathrm{kg}$ body weight, Sandoz K.K., Tokyo, Japan), and butorphanol tartrate $(5 \mathrm{mg} / \mathrm{kg}$ body weight, Meiji Seika Pharma, Tokyo, Japan), pulmonary fibrosis was induced by endotracheal injection of BLM $(2 \mathrm{mg} / \mathrm{kg}$ of body weight, Nippon Kayaku, Tokyo, Japan). Control mice received the same amount $(2 \mathrm{~mL} / \mathrm{kg}$ body weight $)$ of phosphate-buffered saline (PBS, Nacalai Tesque, Kyoto, Japan) alone. For survival analysis, a higher dose of BLM $(5 \mathrm{mg} / \mathrm{kg})$ was used. At 7 and 14 days after BLM administration, both lungs were removed from each animal and the lung tissue was assessed for hydroxyproline, and mRNA expression and subjected to flow cytometry and histological analysis.

\section{Cell isolation}

The lungs were removed and minced in 1-mL Roswell Park Memorial Institute 1640 medium (Thermo Fisher Scientific, Waltham, MA, USA) supplemented with collagenase A (1 mg/mL, Roche, Basel, Switzerland), and incubated at $37{ }^{\circ} \mathrm{C}$ for $30 \mathrm{~min}$. Following lysis of red blood cells with ACK Lysing Buffer (Life Technologies, Grand Island, NY, USA), the cells were resuspended in $2 \mathrm{~mL}$ of PBS containing $0.5 \%$ bovine serum albumin (Sigma-Aldrich, St. Louis, MO, USA) and $2 \mathrm{mM}$ ethylenediaminetetraacetic acid (Sigma-Aldrich), and cell counting was performed. 


\section{Antibodies and ALDH staining}

Antibodies (all purchased from BioLegend, San Diego, CA, USA) used for flow cytometry and cell sorting are shown in Additional file 1. After staining for cell surface proteins using the aforementioned antibodies, ALDH activity was expressed as fluorescent intensity using the ALDEFLUOR $^{\mathrm{TM}}$ Kit (STEMCELL Technologies Inc., Vancouver, Canada) according to the manufacturer's protocol, as previously reported [18]. A separate tube containing $5 \mu \mathrm{L}$ of diethylaminobenzaldehyde (DEAB, provided in the ALDEFLUOR ${ }^{\mathrm{TM}}$ Kit), a specific inhibitor of ALDH, was prepared to determine ALDH ${ }^{\text {br }}$ gating.

\section{Hoechst staining}

Hoechst 33,342 staining of lung cells was performed as previously reported [19]. After suspended in $1 \mathrm{~mL}$ DMEM (Thermo Fisher Scientific) with 5\% FBS (SigmaAldrich), $1.0 \times 10^{6}$ cells were stained with $4 \mu \mathrm{L}$ Hoechst 33,342 (Invitrogen, Carlsbad, CA, USA) alone or in combination with $30 \mu \mathrm{L}$ verapamil (Sigma-Aldrich) for $90 \mathrm{~min}$ at $37^{\circ} \mathrm{C}$ with mixing every 20 min during staining. Antibody and ALDH staining were performed as described above after Hoechst 33,342 staining.

\section{Flow cytometry and cell sorting}

Flow cytometric analysis of lung cells was performed using the following method, referring to a previous report [20]. Flow cytometry and cell sorting were performed using the FACS Aria II system (BD Biosciences, San Jose, CA, USA) and LSRFortessa X-20 (BD Biosciences). Data were analyzed using the FACS Diva (BD Biosciences) and the FlowJo (version 10.7.1, BD Biosciences) software. For the isolation of $\mathrm{ALDH}^{\mathrm{br}}$, unnecessary cell populations were pre-depleted using magnetic cell sorting (MACS) cell separation using a Stem Cell Pre-Enrichment kit (Miltenyi Biotec, Bergisch Gladbach, Germany) prior to FACS according to the manufacturer's protocol. Cell sorting from mCherry-expressing donor mice and analysis of injected donor mCherry ${ }^{+}$cells was performed using the SORP Aria (BD Biosciences) and LSRFortessa X-20 (BD Biosciences) systems, respectively.

\section{Cell culture and colony-forming assay}

Sorted cells were seeded into 96-well plates at a density of $5-10 \times 10^{3}$ cells/well and cultured in Dulbecco's modified Eagle medium (DMEM, Thermo Fisher Scientific) and $10 \%$ fetal bovine serum (FBS, Sigma-Aldrich) supplemented with or without $20 \mathrm{ng} / \mathrm{mL}$ epidermal growth factor (EGF, BioLegend) or $20 \mathrm{ng} / \mathrm{mL}$ fibroblast growth factor-2 (FGF2, BioLegend) or both. The medium was changed every 3-4 days. For colony formation, $5.0 \times 10^{3}$ cells were seeded into 6-well plates using MethoCult
(STEMCELL Technologies Inc.). Consecutively, 2 to 3 weeks after the start of culture, the number of proliferated colonies was counted.

\section{Cell viability assay}

Cells were seeded into 96-well plates at a density of $5.0 \times 10^{3}$ cells/well and the medium was changed every 3-4 days. After 3-4 weeks from the start of the culture, cell proliferation was evaluated using Cell Counting Kit-8 (Dojindo, Kumamoto, Japan).

\section{Cell transfer to recipient mouse}

Sorted $1.0 \times 10^{5} \mathrm{CD} 45^{-} / \mathrm{ALDH}^{\mathrm{br}}$ and $\mathrm{CD} 45^{-} / \mathrm{ALDH}-$ dim cells were dissolved in $100 \mu \mathrm{L}$ PBS and administered intravenously via the tail vein to recipient BLM-pretreated mice on day 2 (2 days after treatment with BLM). To confirm the localization of transferred cells, $5.0 \times 10^{4}$ mCherry $^{+} \mathrm{CD} 45^{-} / \mathrm{ALDH}^{\mathrm{br}}$ and $\mathrm{CD} 45^{-} / \mathrm{ALDH}^{\mathrm{dim}}$ cells were administered intravenously into recipient BLM-pretreated C57BL/ 6 mice on day 2. On the following day and 5 days after the injection (on days 3 and 7), the recipient mice were sacrificed, and lung samples were subjected to flow cytometry and histology analyses.

\section{Hydroxyproline assay}

The left lungs were removed and the sample was homogenized in $1 \mathrm{~mL}$ of PBS and hydrolyzed with $1 \mathrm{~mL}$ of $\mathrm{HCl}$ for $16 \mathrm{~h}$ at $120^{\circ} \mathrm{C}$. The supernatant was centrifuged at 10,000 $g$ for 5 min (Model 3740, KUBOTA, Tokyo, Japan), and $5 \mu \mathrm{L}$ of the supernatant was aliquoted into a 96-well plate. After dispensing $5 \mu \mathrm{L}$ hydroxyproline standard (Sigma-Aldrich) into each well of the 96-well plate, 5 $\mu \mathrm{L}$ citrate/acetate buffer (deionized distilled water supplemented with $238 \mathrm{mM}$ Citric acid, Sigma-Aldrich, $1.2 \%$ glacial acetic acid, Sigma-Aldrich, $532 \mathrm{mM}$ sodium acetate, Sigma-Aldrich, and $850 \mathrm{mM}$ sodium hydroxide, Nacalai Tesque) and $100 \mu \mathrm{L}$ chloramine $\mathrm{T}$ solution $(1.0 \mathrm{~mL}$ deionized distilled water supplemented with $0.141 \mathrm{~g}$ chloramine T, Sigma-Aldrich, $1.0 \mathrm{~mL}$ 1-propanol, Sigma-Aldrich, and $8.0 \mathrm{~mL}$ citrate/acetate buffer) were added. After $30 \mathrm{~min}$ of incubation at $25{ }^{\circ} \mathrm{C}, 100 \mu \mathrm{L}$ of Ehrlich's reagent (2.5 g 4-dimethylaminobenzaldehyde, Sigma-Aldrich, $9.3 \mathrm{~mL}$ 1-propanol, and $3.9 \mathrm{~mL} \mathrm{70 \%} \mathrm{per-}$ chloric acid, Sigma-Aldrich) was added and the mixture was incubated at $65^{\circ} \mathrm{C}$ for $30 \mathrm{~min}$. After $5 \mathrm{~min}$ at $25^{\circ} \mathrm{C}$, the absorbance was measured at $550 \mathrm{~nm}$ using a plate reader (iMARK, Bio-Rad, Hercules, CA, USA), as previously described [21].

\section{PCR and agarose gel electrophoresis}

The sorted cells and the excised lungs were homogenized using $1 \mathrm{~mL}$ TRIzol reagent (Life Technologies) and total 
RNA was extracted using the RNeasy Mini Kit (QIAGEN, Venlo, Netherlands). The extracted RNA was reverse transcribed into cDNA using the High Capacity RNA-to-cDNA Kit (Applied Biosystems, Foster City, CA, USA). Real-time quantitative PCR was performed using the Applied Biosystems 7500 Fast Real-Time PCR System (Applied Biosystems) and the TaqMan Gene Expression Assays (Applied Biosystems) as previously described [16]. The expression of Actb ( $\beta$-actin, Mm02619580_g1; Applied Biosystems) was used as an endogenous control. The TaqMan Gene Expression Assays were used as shown in Additional file 2. To distinguish the mCherry-heterozygotic mice the from wildtype mice, mouse-tail DNA was extracted using the DNeasy Blood and Tissue Kit (QIAGEN). The extracted DNA was subjected to PCR using the primers shown in Additional file 2. PCR conditions were as follows: $120 \mathrm{~s}$ at $94{ }^{\circ} \mathrm{C}, 10 \mathrm{~s}$ at $98{ }^{\circ} \mathrm{C}, 30 \mathrm{~s}$ at $60{ }^{\circ} \mathrm{C}, 120 \mathrm{~s}$ at $68^{\circ} \mathrm{C}$, repeated for 30 cycles. Amplified products were stained with SAFELOOK ${ }^{\mathrm{TM}}$ (Fujifilm Wako Junyaku, Osaka, Japan), and bands were confirmed using electrophoresis on a $1 \%$ agarose gel.

\section{Histological analysis}

Lung tissue sections were fixed in $2 \%$ formalin solution (Nacalai Tesque, Kyoto, Japan) and embedded in paraffin, followed by hematoxylin-eosin (HE) and Masson's trichrome staining. Immunostaining for ALDH1A1 and mCherry was performed using an anti-ALDH1A1 rabbit polyclonal antibody (dilution factor 1:500; GTX123973, GeneTex, Irvine, CA, USA) and anti-mCherry rabbit polyclonal antibody (dilution factor 1:400; ab167453, Abcam, Cambridge, UK), respectively, as the primary antibodies and a peroxidase-conjugated anti-rabbit goat IgG polyclonal antibody (ready to use; \#424144, Nichirei, Tokyo, Japan) as the secondary antibody.

\section{Statistical analyses}

All experiments were performed 2 or 3 times and the representative data are shown as median \pm interquartile range except for mRNA data, which is shown as mean \pm SEM to ensure the visibility of the graph. The Kruskal-Wallis test for median values was used to assess the statistical significance between groups. Correlation coefficients for parameters were calculated using the Spearman's rank correlation coefficient analysis. KaplanMeier analysis and log-rank test were used for survival analysis. A $P$ value $<0.05$ was considered significant. All statistical analyses were performed using JMP Pro 14 (SAS Institute Inc., Cary, NC, USA).

\section{Results}

\section{Detection of $A L D H^{\text {br }}$ in mouse lung}

Following the determination of the appropriate $\mathrm{ALDH}^{\mathrm{br}}$ gating using ALDEFLUOR staining with the DEAB
ALDH inhibitor, we observed a rare $\mathrm{ALDH}^{\mathrm{br}}$ population in the whole lung of mice (Fig. 1A). When we divided the whole lung cells into $\mathrm{CD} 45^{+}$hematopoietic cells and $\mathrm{CD}^{-} 5^{-}$nonhematopoietic cells (Fig. 1B), we noted that both fractions contained $\mathrm{ALDH}^{\mathrm{br}}$ (Fig. $\left.1 \mathrm{C}, \mathrm{D}\right)$. To assess lung resident $A L D H^{\text {br }}$, we focused on the nonhematopoietic $\mathrm{CD}_{4} 5^{-} / \mathrm{ALDH}^{\mathrm{br}}$ fraction. Analysis of these nonhematopoietic cells, that is, the lung resident $\mathrm{CD}_{4} 5^{-}$/ $\mathrm{ALDH}^{\mathrm{br}}$ fraction, revealed that this fraction was further divided into mesenchymal (platelet-derived growth factor receptor $\alpha$ positive, PDGFR $\alpha^{+}$) and epithelial (epithelial cell adhesion molecule positive, EpCAM ${ }^{+}$) phenotypes (Fig. 1E).

\section{Characteristics of lung CD45-/ALDH ${ }^{\text {br }}$}

To determine the characteristics of lung CD45-/ALD$\mathrm{H}^{\mathrm{br}}$, we collected $\mathrm{CD} 45^{-} / \mathrm{ALDH}^{\mathrm{br}}(n=3)$ and $\mathrm{CD} 45^{-} /$ $\operatorname{ALDH}^{\operatorname{dim}}(n=3)$ cells using FACS. As shown in Additional file 3 , pre-depletion of unnecessary cell populations prior to FACS resulted in the enrichment of the $\mathrm{CD}_{4} 5^{-} / \mathrm{ALDH}^{\mathrm{br}}$ fraction. To confirm if sorted $\mathrm{CD}^{-} 5^{-} /$ $\mathrm{ALDH}^{\mathrm{br}}$ cells truly expressed high levels of ALDH mRNA and to determine the isoforms of ALDH that were mainly expressed in $\mathrm{CD}_{4} 5^{-} / \mathrm{ALDH}^{\mathrm{br}}$ cells, we performed realtime quantitative PCR. Our results showed that the levels of mRNA expression of ALDH1a, ALDH2, ALDH3a1, $A L D H 4 a 1, A L D H 7 a 1$, and $A L D H 18 a$ were significantly higher in the $\mathrm{CD} 45^{-} / \mathrm{ALDH}^{\mathrm{br}}$ than in the CD45 $/ \mathrm{ALD}$ $\mathrm{H}^{\text {dim }}$ cells (Fig. 2A, $P=0.049$ for ALDH1a1, $P=0.049$ for ALDH1a2, $P=0.049$ for ALDH1a3, $P=0.037$ for $A L D H 1 a 7, P=0.049$ for $A L D H 2, P=0.046$ for $A L D H 3 a 1$, $P=0.049$ for ALDH4a1, $P=0.037$ for ALDH7a1, and $P=0.049$ for $A L D H 18 a$ ). We further observed that when both cell populations were cultured, the CD45-/ALD$\mathrm{H}^{\mathrm{br}}$ population showed higher proliferative ability than the $\mathrm{CD} 45^{-} / \mathrm{ALDH}^{\mathrm{dim}}$ population (Fig. $2 \mathrm{~B}, \mathrm{C}, P=0.009$ between $\mathrm{CD}^{-} 5^{-}$and $\mathrm{CD} 45^{-} / \mathrm{ALDH}^{\mathrm{br}}$ and $P=0.009$ between $\mathrm{CD}_{4} 5^{-} / \mathrm{ALDH}^{\mathrm{dim}}$ and $\left.\mathrm{CD} 45^{-} / \mathrm{ALDH}^{\mathrm{br}}\right)$. To examine whether $\mathrm{CD}_{4} 5^{-} / \mathrm{ALDH}^{\mathrm{br}}$ cells maintained a high ALDH activity in culture, sorted $\mathrm{CD} 45^{-} / \mathrm{ALDH}^{\text {br }}$ cells were further cultured, harvested, and reexamined for ALDH activity. As shown in Fig. 3A, most proliferated cells were ALDH ${ }^{\mathrm{dim}}$, with $\mathrm{ALDH}^{\mathrm{br}}$ cells accounting for approximately $5 \%$ of the total proliferative cells.

Next, we examined the colony-forming ability of CD45 ${ }^{-} / \mathrm{ALDH}^{\mathrm{br}}$ cells using a colony-forming assay. We found that $\mathrm{CD}_{4} 5^{-} / \mathrm{ALDH}^{\mathrm{br}}$ cells formed larger (Fig. 2D) and higher number (Fig. 2E) of colonies than the $\mathrm{CD}_{4}{ }^{-} /$ $\mathrm{ALDH}^{\mathrm{dim}}$ cells. Although a similar pattern of colony formation was observed for $\mathrm{CD}_{4} 5^{-}$, the size and the number of colonies were relatively small, suggesting that the colony-forming ability of the $\mathrm{CD} 45^{-}$population depended to a large extent on the CD45-/ALDH ${ }^{\text {br }}$ cells. 


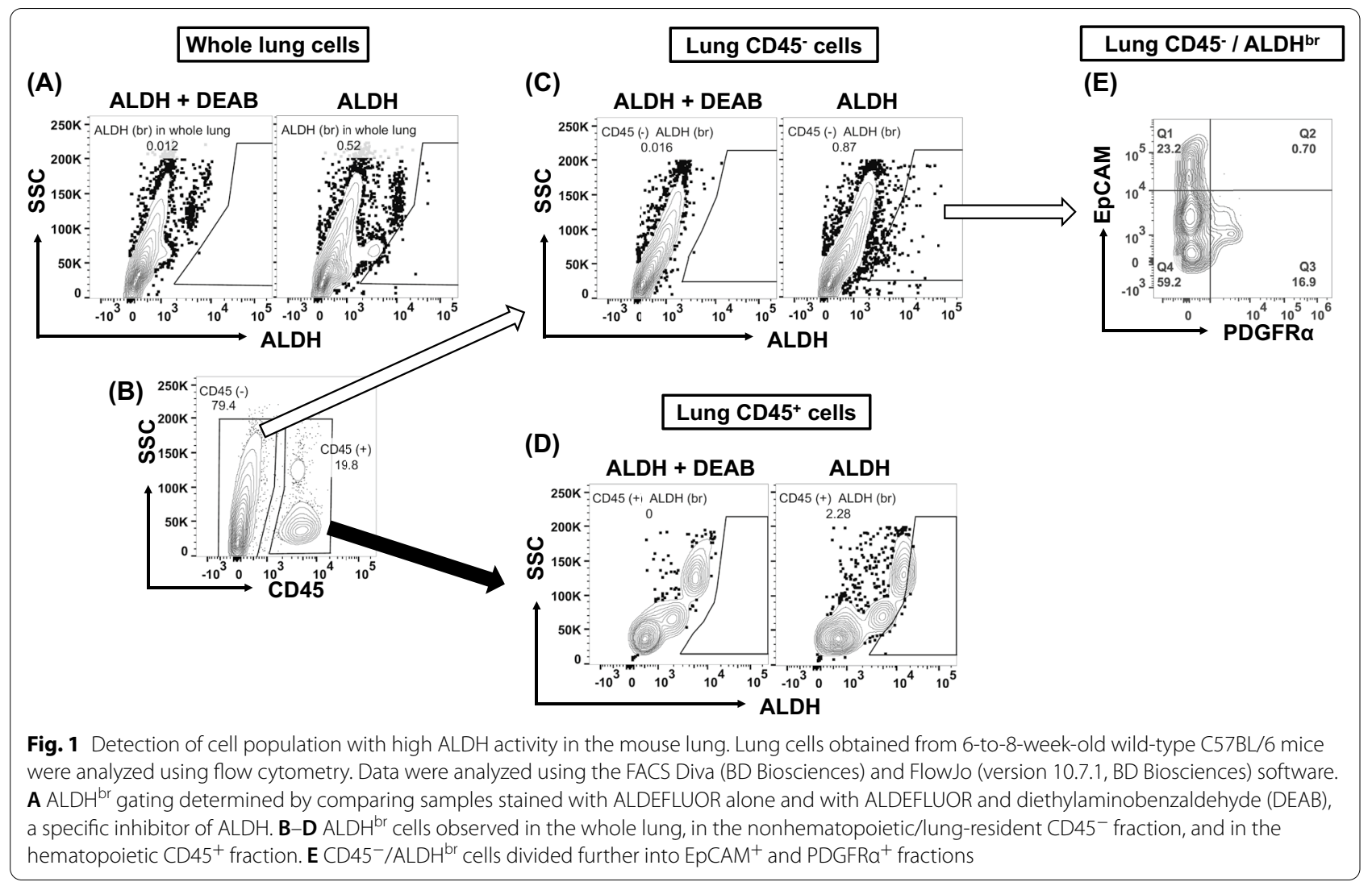

As the $\mathrm{CD} 45^{-} / \mathrm{ALDH}^{\mathrm{br}}$ population seemed to be a heterogeneous cell population and $\mathrm{ALDH}^{\mathrm{br}}$ is associated with stemness in various tissues, we evaluated the expression of surface antigens associated with the mesenchymal cells, fibroblasts, and the stem cells in the CD45 / $\mathrm{ALDH}^{\mathrm{br}}$ population. As shown in Additional file 4, not all $\mathrm{CD} 45^{-} / \mathrm{ALDH}^{\mathrm{br}}$ cells expressed the representative markers of bone marrow-derived MSCs (CD44, CD73, CD90, and CD105). It was notable that the stage-specific embryonic antigen-4 (SSEA4) stem cell marker was solely expressed in $\mathrm{CD}_{4} 5^{-} / \mathrm{ALDH}^{\mathrm{br}}$ cells in the mouse lung.

When we divided the $\mathrm{CD} 45^{-} / \mathrm{ALDH}^{\mathrm{br}}$ population into $\mathrm{CD}_{4} 5^{-} / \mathrm{ALDH}^{\mathrm{br}} / \mathrm{PDGFR} \alpha^{+}$and $\mathrm{CD} 45^{-} / \mathrm{ALDH}^{\mathrm{br}} /$ $\mathrm{EpCAM}^{+}$population, and investigated their characteristics, we observed that the CD $45^{-} / \mathrm{ALDH}^{\mathrm{br}} / \mathrm{PDGFR}^{+}$ population exhibited a fibroblast-like spindle shape, whereas the $\mathrm{CD}_{4} 5^{-} / \mathrm{ALDH}^{\mathrm{br}} / \mathrm{EpCAM}^{+}$population exhibited a flat and round shape (Fig. 2F). We also found that growth factors led to an increase in the number of $\mathrm{CD}_{4} 5^{-} / \mathrm{ALDH}^{\mathrm{br}} / \mathrm{PDGFR}^{+}$cells but not that of $\mathrm{CD}^{-} 5^{-} /$ $\mathrm{ALDH}^{\mathrm{br}} / \mathrm{EpCAM}^{+}$cells, suggesting that $\mathrm{CD} 45^{-} / \mathrm{ALDH}^{\mathrm{br}} /$ $\mathrm{PDGFR \alpha}^{+}$fraction contributed to the high proliferative potential of the $\mathrm{CD}_{4} 5^{-} / \mathrm{ALDH}^{\mathrm{br}}$ population (Fig. $2 \mathrm{~F}$ ).

Next, we examined the expression of ALDH in primary cultured lung fibroblasts (Fig. 3A). These primary cultured lung fibroblasts obtained from BLM-untreated wild-type $\mathrm{C} 57 \mathrm{BL} / 6$ mice were shown to frequently express PDGFR $\alpha$, but not CD45 or EpCAM, suggesting that these cells were truly fibroblasts (Fig. 3B). As shown in Fig. 3C, both fluorescent microscopy and flow cytometry revealed that the percentage of ALDH ${ }^{\text {br }}$ cells in primary cultured lung fibroblasts was approximately $5 \%$. Similarly, we noted that the percentage of ALDH ${ }^{\text {br }}$ cells in fibroblast cell lines was also less than 5\% (Fig. 3D).

\section{Kinetics of $C D 45^{-} / A L D H^{b r}$ in BLM-induced pulmonary fibrosis}

To investigate the kinetics of $\mathrm{CD} 45^{-} / \mathrm{ALDH}^{\mathrm{br}}$ in fibrotic lungs, we used endotracheal administration of BLM ( $2 \mathrm{mg} / \mathrm{kg}$ body weight) to generate a mouse model of pulmonary fibrosis. We found that the levels of hydroxyproline were significantly elevated in the BLM group $(n=9)$ 14 days after BLM administration (Fig. 4A, $P=0.005$ ) compared with the PBS group $(n=4)$. On days 7 and 14 , the percentage of total ALDH ${ }^{\text {br }}$ cells in the lung was significantly elevated compared with that on day 0 (Fig. 4B), whereas the percentage of $\mathrm{CD} 45^{-} / \mathrm{ALDH}^{\mathrm{br}}$ cells and $\mathrm{CD}_{4} 5^{-} / \mathrm{ALDH}^{\mathrm{br}} / \mathrm{PDGFR}^{+}$cells, but not $\mathrm{CD} 45^{-} / \mathrm{ALD}$ $\mathrm{H}^{\text {br }} / \mathrm{EpCAM}^{+}$cells, were significantly decreased (Fig. 4B). Among the $\mathrm{ALDH}^{\mathrm{br}}$ populations in the lung obtained on 


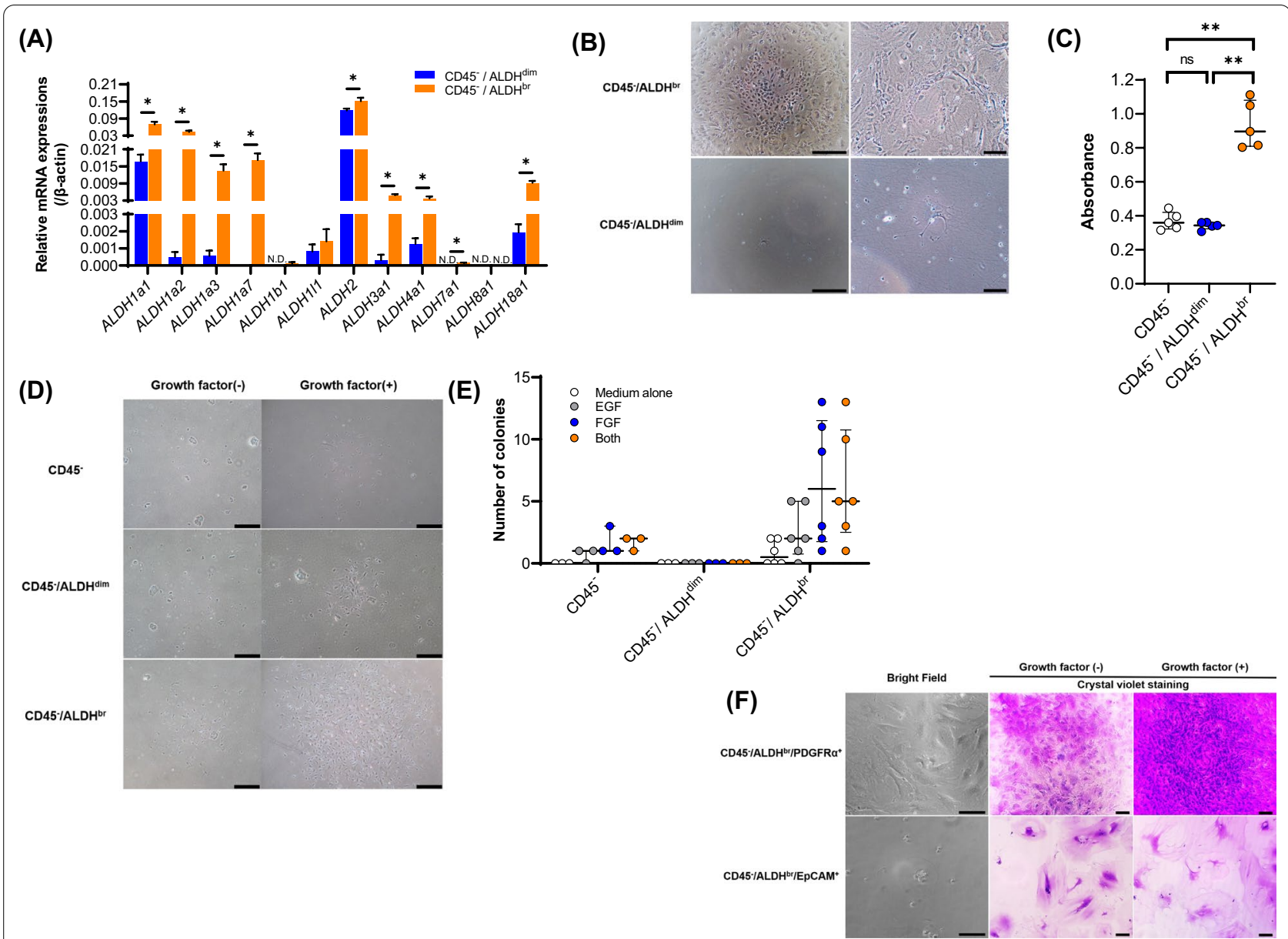

Fig. 2 A Real-time quantitative PCR analysis of the mRNA expression levels of ALDH isoforms in sorted CD45-/ALDH ${ }^{\text {br }}(n=3)$ and CD45 $-/ A L D H^{\text {dim }}$ cells (cell population with low ALDH activity, $n=3$ ). Values are expressed relative to the expression of the endogenous control $\beta$-actin mRNA. Data are shown as mean \pm SEM. ${ }^{*} P<0.05$, N.D., not detectable. B Representative image of cultured cells (left, low-power field, scale bar, $400 \mu \mathrm{m}$, right, high-power field, scale bar, $100 \mu \mathrm{m})$. C The proliferative capacity of cells using a CCK-8 kit ( $n=5 /$ group), as shown in (B). ** $P<0.01$. D Representative image of colonies derived from the colony-forming assay using MethoCult supplemented with or without growth factors. Scale bar, $400 \mu \mathrm{m}$. E The number of colonies derived from the colony-forming assay in (D). F Representative image of sorted cell populations cultured with or without growth factors. The bright field and cells stained with crystal violet are shown. Scale bar, $70 \mu \mathrm{m}$. G Sorted CD45-/ALDH ${ }^{\mathrm{br}} / \mathrm{PDGFRa}^{+}$cells induced for differentiation into adipocytes and stained with Oil red O. Scale bar, $70 \mu \mathrm{m}$

day 14 , the percentage of $\mathrm{CD}_{4} 5^{-} / \mathrm{ALDH}^{\mathrm{br}} / \mathrm{PDGFR}^{+}$ cells, but not that of $\mathrm{CD}_{4} 5^{-} / \mathrm{ALDH}^{\mathrm{br}}$ cells or $\mathrm{CD} 45^{-} /$ $\mathrm{ALDH}^{\mathrm{br}} / \mathrm{EpCAM}^{+}$cells, inversely correlated with the levels of hydroxyproline (Fig. 4C).

Real-time quantitative PCR analysis revealed that the mRNA expression of ALDH1a1, ALDH1a7, ALDH1l1, $A L D H 2, A L D H 3 a 1, A L D H 4 a 1$, and ALDH7a1 was significantly lower in the fibrotic lung obtained on day 14 (Fig. 4D, $P=0.006$ for ALDH1a1, $P=0.006$ for ALDH1a7, $P=0.014$ for ALDH1l1, $P=0.006$ for $A L D H 2, P=0.006$ for ALDH3a1, $P=0.006$ for $A L D H 4 a 1$, and $P=0.009$ for ALDH7a1). Consistent with the reduced number of $\mathrm{CD} 45^{-} / \mathrm{ALDH}^{\mathrm{br}}$ cells and the reduced expression of ALDH1a1 mRNA in the fibrotic lung, the expression of ALDH1a1 was reduced throughout the alveolar epithelia, especially in the areas of fibrosis, as demonstrated using immunostaining (Additional file 5).

The decrease in number of cells observed in $\mathrm{CD} 45^{-} /$ $\mathrm{ALDH}^{\mathrm{br}}$ cells during BLM treatment was a feature observed in lung SP cells as well [10]. Therefore, we investigated the possibility of an overlap between $\mathrm{ALDH}^{\mathrm{br}}$ and lung SP cells. After Hoechst staining, ALDH staining was performed, followed by flow cytometry, which revealed that $\mathrm{CD} 45^{-} / \mathrm{ALDH}^{\mathrm{br}}$ population is completely different from $\mathrm{CD} 45^{-}$lung SP cells (Additional file 6). 


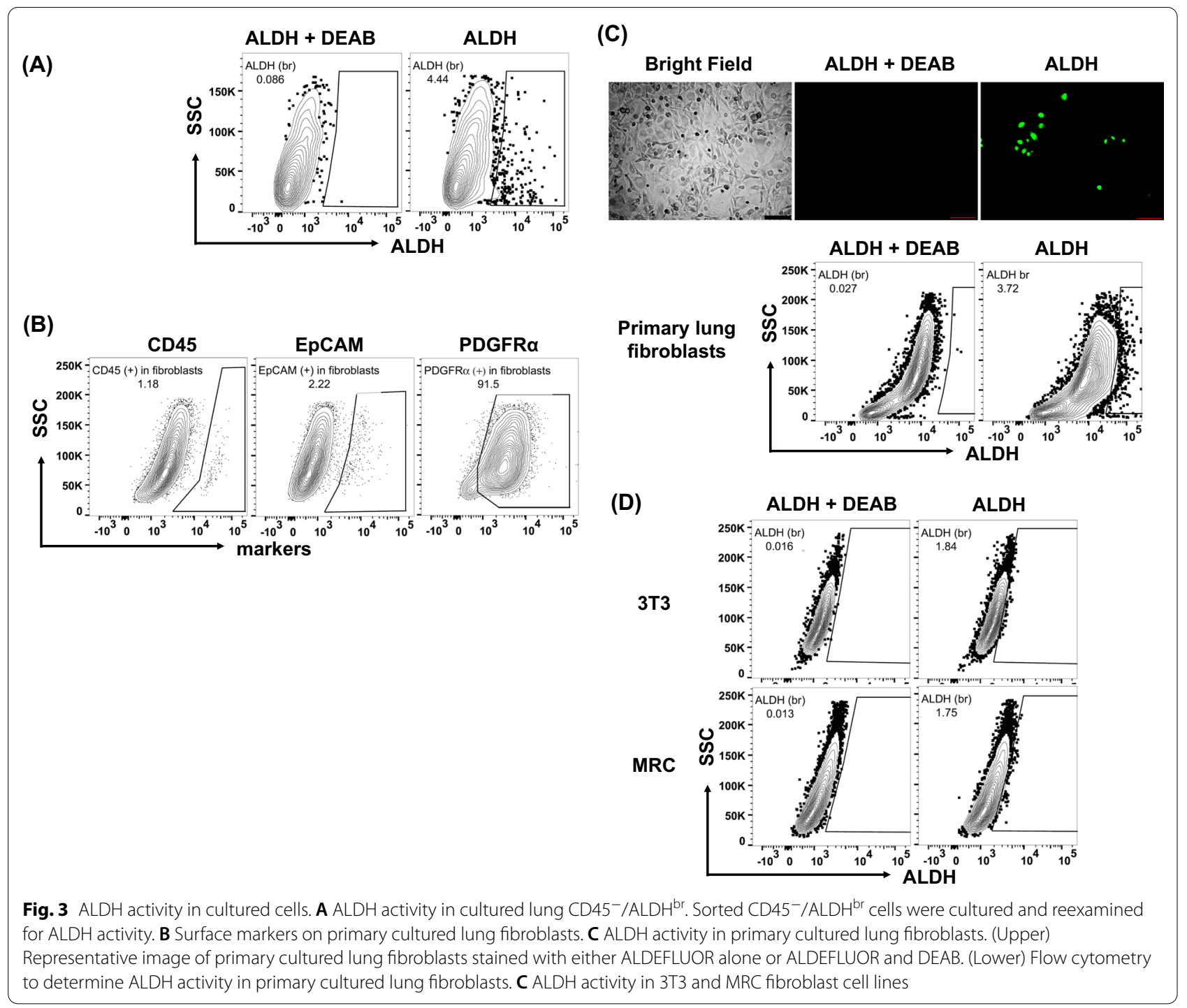

\section{Effect of $C D 45^{-} / A L D H^{\text {br }}$ cell therapy on BLM-induced pulmonary fibrosis}

In the preceding experiments, we presumed that $\mathrm{CD} 45^{-} /$ $\mathrm{ALDH}^{\mathrm{br}}$ cells were depleted during pulmonary fibrosis; therefore, we assessed the possible usage of $\mathrm{CD}_{4} 5^{-} /$ $\mathrm{ALDH}^{\mathrm{br}}$ cells in cell therapy for BLM-induced pulmonary fibrosis. Our results showed that both the levels of hydroxyproline (Fig. 5A, $P=0.023$ ) and the degree of tissue fibrosis (Fig. 5B for HE staining, Additional file 7 for Masson's trichrome staining) in the lung obtained on day 14 were significantly lower in the CD45/ALD$\mathrm{H}^{\text {br }}$ i.v. group $(n=4)$ than in the $\mathrm{CD} 45^{-} / \mathrm{ALDH}^{\mathrm{dim}}$ i.v. group $(n=7)$. In the $\mathrm{CD} 45^{-} / \mathrm{ALDH}^{\mathrm{br}}$ i.v. group $(n=7-8)$, the mRNA expression of interleukin 6 (IL6) and transforming growth factor $\beta 1$ (TGFb1) genes in lung tissues obtained on day 7 was significantly suppressed compared with the $\mathrm{CD} 45^{-} / \mathrm{ALDH}^{\mathrm{dim}}$ i.v. group $(n=9-10)$ (Fig. $5 \mathrm{C}$, $P=0.042$ for $I L 6$, and $P=0.013$ for TGFb1). Interestingly, we noted that the percentage of $\mathrm{CD} 45^{-} / \mathrm{ALDHbr} /$ PDGFR $\alpha^{+}$cells, which was lowered, was recovered in the $\mathrm{CD} 45^{-} / \mathrm{ALDH}^{\mathrm{br}}$ i.v. group $(n=4)$ in the lung obtained on day 14 (Fig. 5D). Furthermore, the expression levels of ALDH1a1 and ALDH4a1 mRNAs, which were significantly reduced after treatment with BLM (Fig. 4D), were also recovered in the $\mathrm{CD} 45^{-} / \mathrm{ALDH}^{\mathrm{br}}$ i.v. group $(n=4)$ on day 14 (Fig. $5 \mathrm{E}, P=0.008$ for $A L D H 1 a 1$, and $P=0.038$ for ALDH4a1).

Among the ALDH family of enzymes, the ALDH1a family (ALDH1a1, ALDH1a2, and ALDH1a3), also known as retinal dehydrogenases or retinaldehyde dehydrogenases (RALDH), convert retinal/retinaldehyde to all-trans retinoic acid (ATRA) (Fig. 5F) [22]. 
(A)

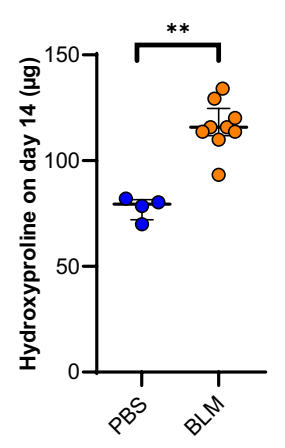

(B)

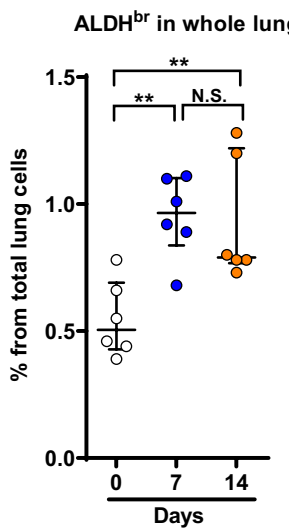

CD45/ALDH ${ }^{\text {br }}$

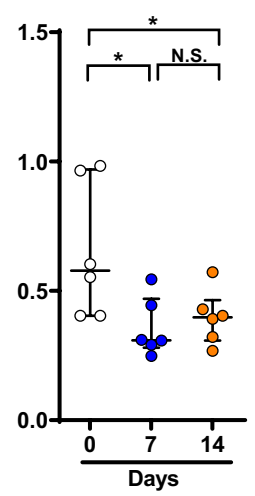

$\mathrm{CD}^{\circ} / \mathrm{ALDH}^{\mathrm{br}} / \mathrm{EpCAM}^{+}$

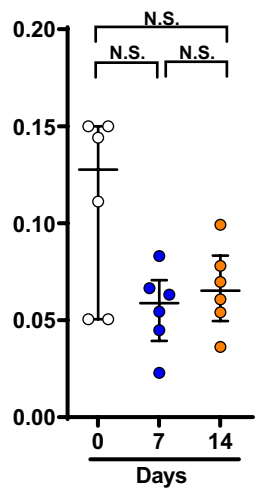

$\mathrm{CD}^{2} /$ /ALDH $^{\text {br }} /$ PDGFR $^{+}$

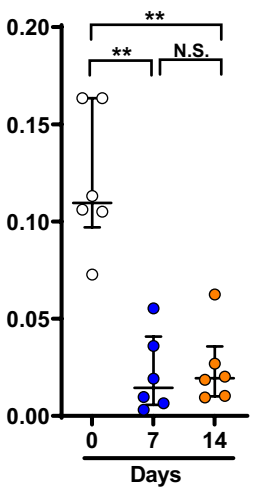

(C)
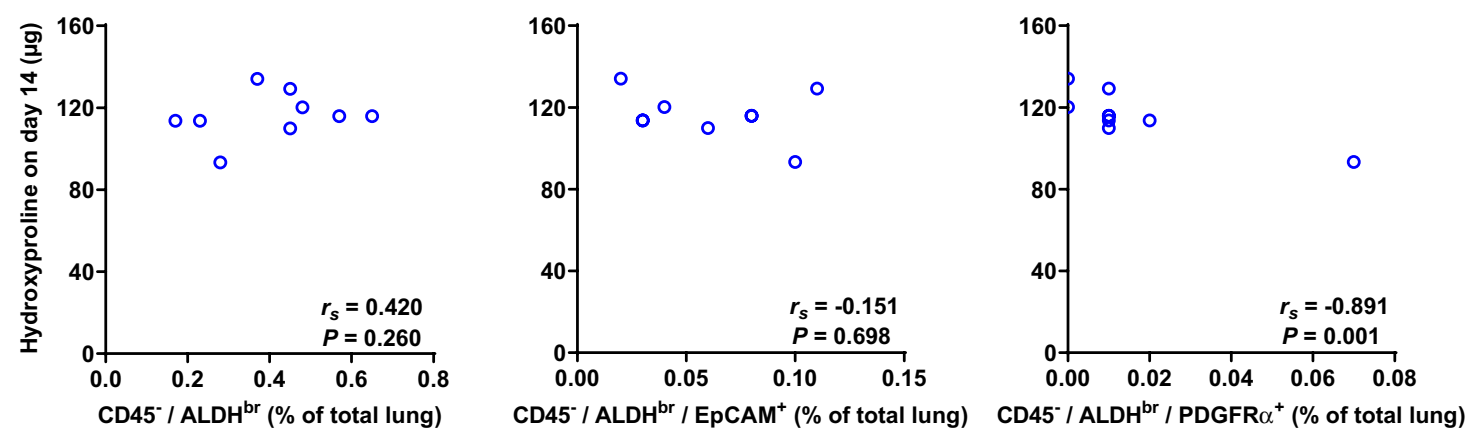

(D)

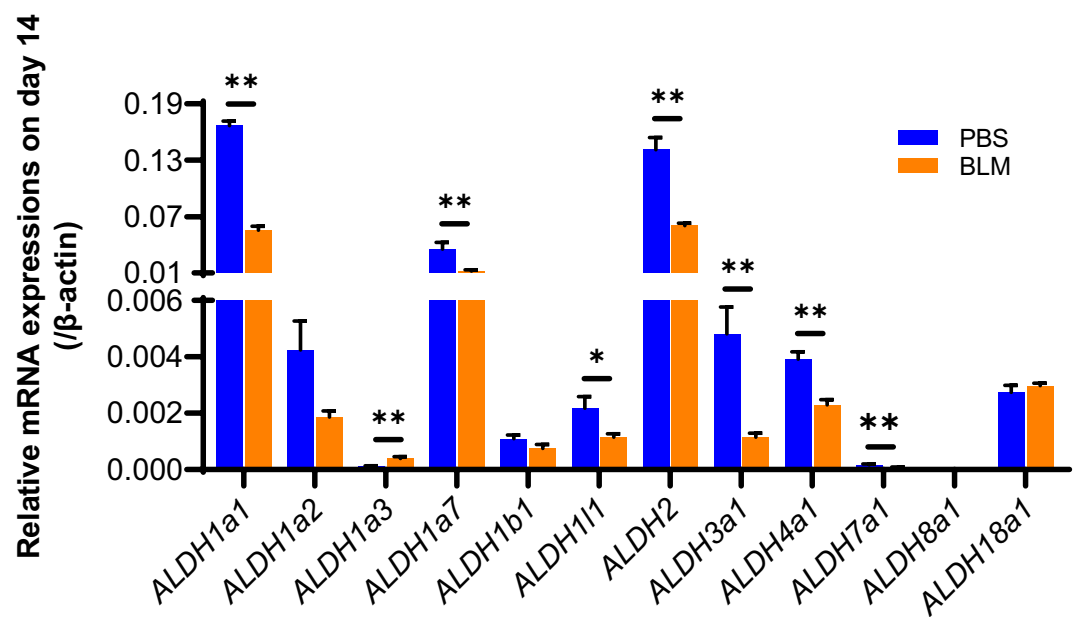

Fig. 4 Decreased CD45-/ALDH ${ }^{\text {br }}$ during pulmonary fibrosis. A Lung hydroxyproline content on day 14 in the PBS $(n=4)$ and the BLM $(n=9)$ groups. ${ }^{*} P<0.01$. B Percentages of $A L D H^{\text {br }}, \mathrm{CD}^{*} 5^{-} / \mathrm{ALDH}^{\mathrm{br}}, \mathrm{CD}^{-} 5^{-} / \mathrm{ALDH}^{\mathrm{br}} / \mathrm{EPCAM}{ }^{+}$, and $\mathrm{CD} 45^{-} / \mathrm{ALDH}^{\mathrm{br}} / \mathrm{PDGFRa}^{+}$cells in total lung cells during BLM-induced pulmonary fibrosis $\left(n=6 /\right.$ group). ${ }^{*} P<0.05,{ }^{*} P<0.01$. ns, not significant. C Correlations between lung hydroxyproline content on day 14 and percentages of $\mathrm{ALDH}^{\mathrm{br}}, \mathrm{CD}^{-} 5^{-} / \mathrm{ALDH}^{\mathrm{br}}, \mathrm{CD}^{-} 5^{-} / \mathrm{ALDH}^{\mathrm{br}} / \mathrm{EpCAM}^{+}$, and CD45-/ALDH ${ }^{\mathrm{br}} / \mathrm{PDGFRa}{ }^{+}$cells in total lung cells. D Real-time quantitative PCR analysis of the mRNA expression levels of ALDH isoforms in the lungs obtained from the PBS $(n=4)$ and BLM $(n=9)$ groups on day 14. Values are expressed relative to the expression of the endogenous control $\beta$-actin mRNA. Data are shown as mean \pm SEM. ${ }^{*} P<0.05,{ }^{* *} P<0.01$ 


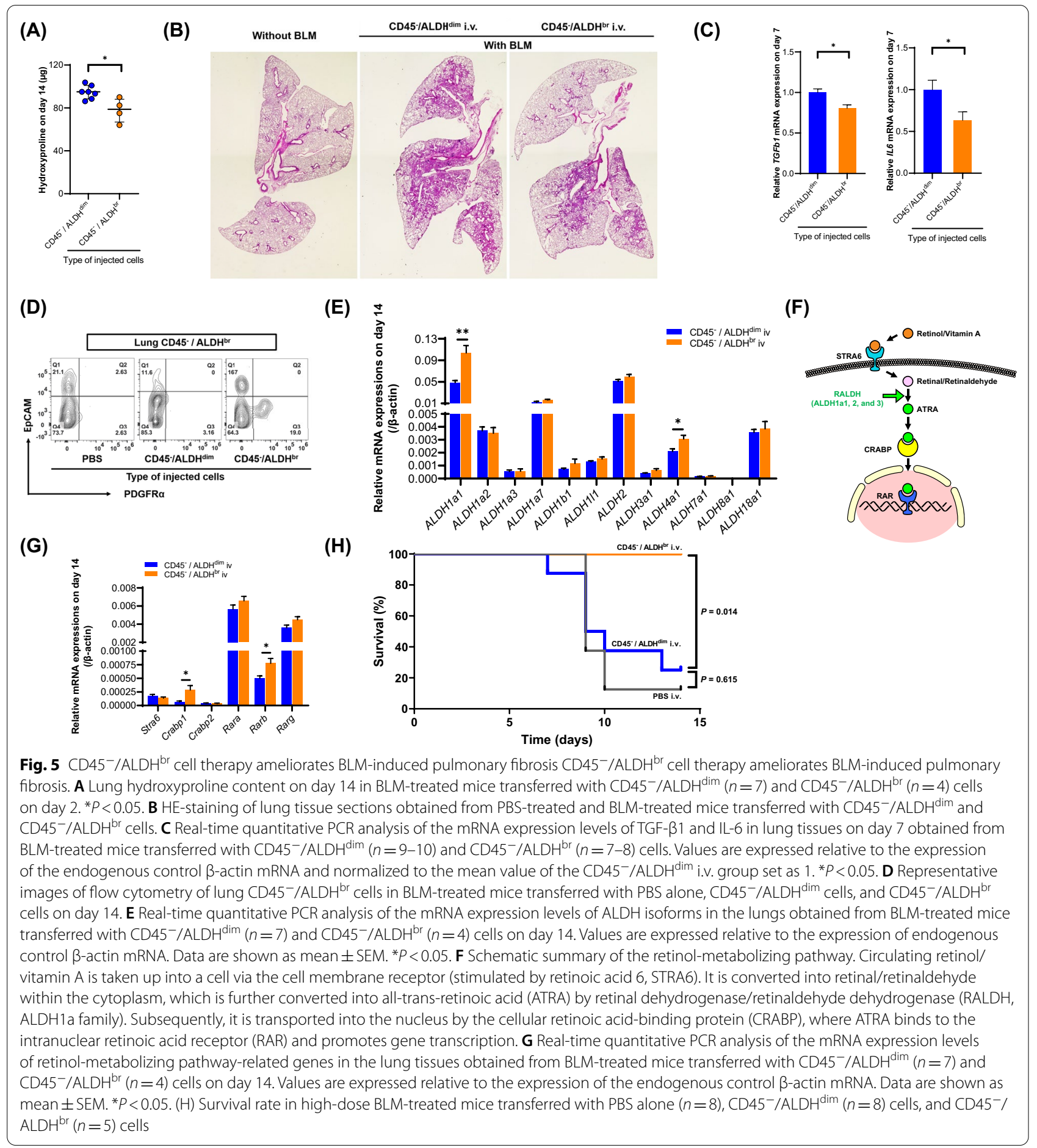

To investigate the effect of the transferred $\mathrm{CD} 45^{-} /$ $\mathrm{ALDH}^{\mathrm{br}}$ cells on the retinol-metabolizing pathway in BLM-induced pulmonary fibrosis, we examined the retinol-metabolizing pathway-related mRNA expression in BLM-treated lung tissue. As shown in Fig. 5G, the mRNA expression levels of cellular retinoic acid-binding protein
1 (Crabp1) and retinoic acid receptor beta (Rarb) were significantly increased in the $\mathrm{CD} 45^{-} / \mathrm{ALDH}^{\mathrm{br}}$ i.v. group $(n=4)$ compared with the $\mathrm{CD} 45^{-} / \mathrm{ALDH}^{\mathrm{dim}}$ i.v. group $(n=7)(P=0.019$ for $C r a b p 1$, and $P=0.038$ for $R a r b)$.

In addition, we assessed the effect of $\mathrm{CD} 45^{-} / \mathrm{ALDH}^{\mathrm{br}}$ cell therapy on survival using BLM-induced pulmonary 
fibrosis with a higher dose of BLM $(5 \mathrm{mg} / \mathrm{kg}$ body weight). We observed that the higher dose of BLM led to approximately $80 \%$ mortality on day 14 in both the $\mathrm{CD}^{2} 5^{-} / \mathrm{ALDH}^{\mathrm{dim}}(n=8)$ and the PBS i.v. groups $(n=8)$, whereas, surprisingly, no death was observed in mice that received $\mathrm{CD} 45^{-} / \mathrm{ALDH}^{\mathrm{br}}$ cell therapy $(n=5)($ Fig. $5 \mathrm{H})$.

\section{Detection of transferred donor $C D 45^{-} / A L D H^{b r}$ in the recipient lung}

To distinguish and trace the injected donor $\mathrm{CD}_{4} 5^{-}$/ $\mathrm{ALDH}^{\mathrm{br}}$ cells in the lungs of recipient mice, mCherry knock-in mice were used as donors. After mCherry heterozygosity was confirmed using tail PCR (Additional file 8), donor $\mathrm{CD} 45^{-} / \mathrm{ALDH}^{\mathrm{br}}$ or $\mathrm{CD} 45^{-} / \mathrm{ALDH}^{\mathrm{dim}}$ cells were sorted from these mCherry-expressing mice using FACS (Fig. 6A) and transferred into wild-type C57BL/6 recipients pretreated with BLM. We observed that flow cytometry could detect donor mCherry-positive CD45 ${ }^{-}$/ $\mathrm{ALDH}^{\mathrm{br}}$ (Fig. 6B) and $\mathrm{CD}^{-} 5^{-} / \mathrm{ALDH}^{\mathrm{br}} / \mathrm{PDGFR}^{+}$ (Fig. 6C) cells in the recipient lungs more frequently in the $\mathrm{CD} 45^{-} / \mathrm{ALDH}^{\mathrm{br}}$ i.v. group than in the $\mathrm{CD} 45^{-} / \mathrm{ALD}$ $\mathrm{H}^{\mathrm{dim}}$ i.v. group. Appropriate mCherry immunostaining conditions were determined using appropriate positive and negative controls (Fig. 6D), and we noted that mCherry-positive $\mathrm{CD} 45^{-} / \mathrm{ALDH}^{\mathrm{br}}$ and $\mathrm{CD} 45^{-} /$ $\mathrm{ADLH}^{\mathrm{br}} / \mathrm{PDGFR}^{+}$cells were also found histologically in the recipient lung-transferred $\mathrm{CD}_{4} 5^{-} / \mathrm{ALDH}^{\mathrm{br}}$ (Fig. 6E).

\section{Effects of aging on ALDH activity}

Finally, we examined the role of aging on the $\mathrm{CD} 45^{-}$/ $\mathrm{ALDH}^{\mathrm{br}}$ population. As shown in Fig. 7A, the percentages of whole $\mathrm{CD} 45^{-} / \mathrm{ALDH}^{\mathrm{br}}$ cell population and that of its $\mathrm{CD} 45^{-} / \mathrm{ALDH}^{\mathrm{br}} / \mathrm{PDGFR}^{+}$subgroup in the lung were not significantly different between aged and young mice that were not treated with BLM (on day 0 ). On the contrary, the percentage of $\mathrm{CD} 45^{-} / \mathrm{ALDH}^{\mathrm{br}} / \mathrm{PDGFR}^{+}$cells, but not $\mathrm{CD} 45^{-} / \mathrm{ALDH}^{\mathrm{br}}$ cells, in the lung obtained 7 days after treatment with BLM was significantly decreased in aged mice $(n=4-6)$ compared with that in young mice $(n=4-6)$. In a similar fashion, the percentage of ALDH ${ }^{\text {br }}$ cells in cultured PDGFR $\alpha$-predominant (as shown in Fig. 3B) primary lung fibroblasts obtained from the lung 7 days after treatment with BLM was significantly

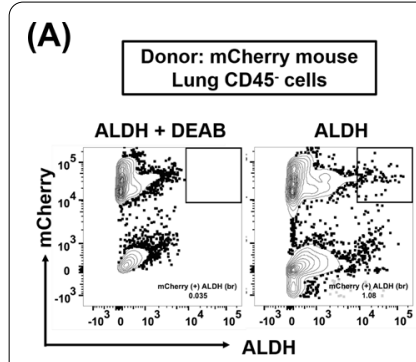

(B)

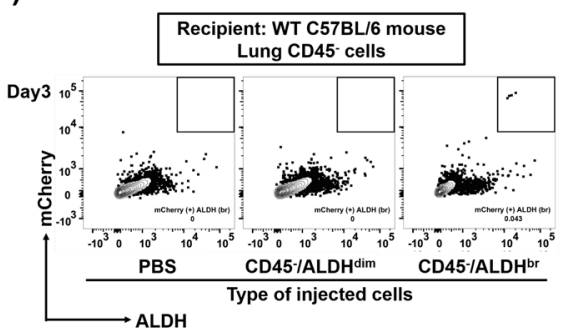

(C)

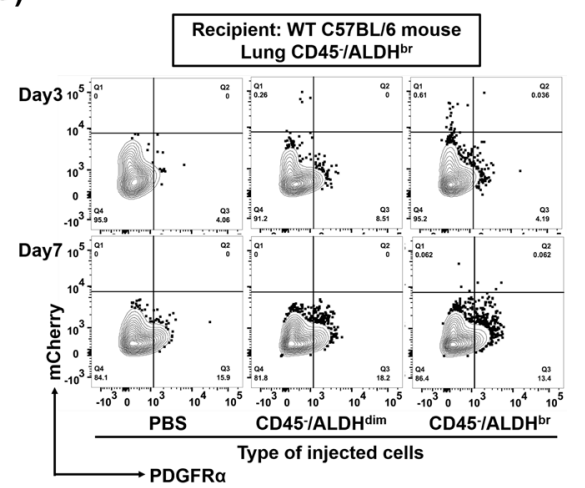

(D)

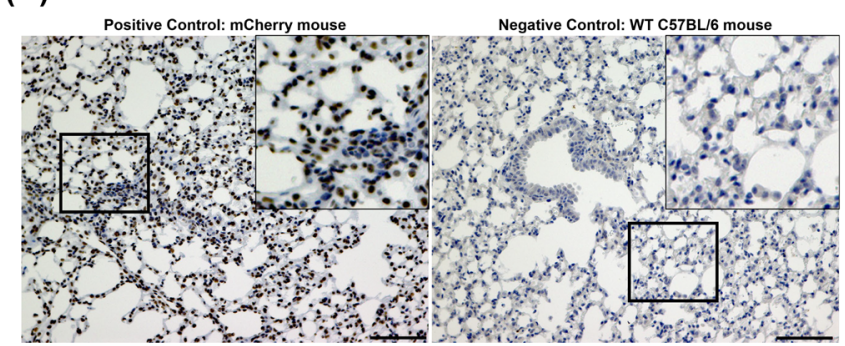

(E)

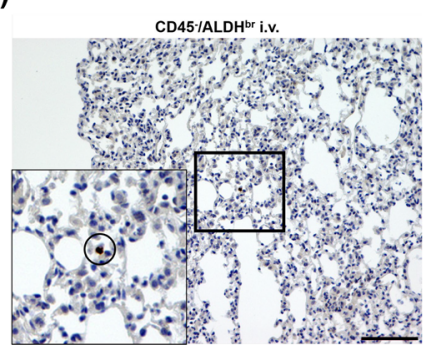

Fig. 6 Detection of transferred donor $C D 45^{-} / A L D H^{\text {br }}$ cells in the recipient lung. A Representative images of flow cytometry of lung $C D 45^{-}$cells in donor mCherry-expressing mice. B Flow cytometry of lung CD45- cells in recipient BLM-treated C57BL/6 mice transferred with PBS alone, donor $\mathrm{mCherry}^{+} / \mathrm{CD} 5^{-} / \mathrm{ALDH}^{\text {dim }}$ cells, and donor $\mathrm{mCherry}{ }^{+} / \mathrm{CD}^{2} 5^{-} / \mathrm{ALDH}^{\mathrm{br}}$ cells. Recipient lungs were harvested on the day following the cell transfer (day 3, 3 days after BLM-treatment). C Flow cytometry of lung CD45-/ALDH ${ }^{\text {br }}$ cells in recipient BLM-treated C57BL/6 mice transferred with PBS alone, donor $\mathrm{mCherry}+\mathrm{CD} 45^{-} / \mathrm{ALDH}^{\mathrm{dim}}$ cells, and donor mCherry ${ }^{+} / \mathrm{CD}^{-} 5^{-} / \mathrm{ALDH}^{\mathrm{br}}$ cells. Recipient lungs were harvested the next day and 5 days after cell transfer (days 3 and 7). D Histological analysis of mCherry immunostaining in lungs obtained from mCherry-expressing mice (positive control) and wild-type (57BL/6 mice (negative control). E Representative images of mCherry immunostaining in lungs obtained from recipient BLM-treated wild-type C57BL/6 mice transferred with mCherry ${ }^{+} / \mathrm{CD}_{4} 5^{-} / \mathrm{ALDH}^{\mathrm{br}}$ cells 


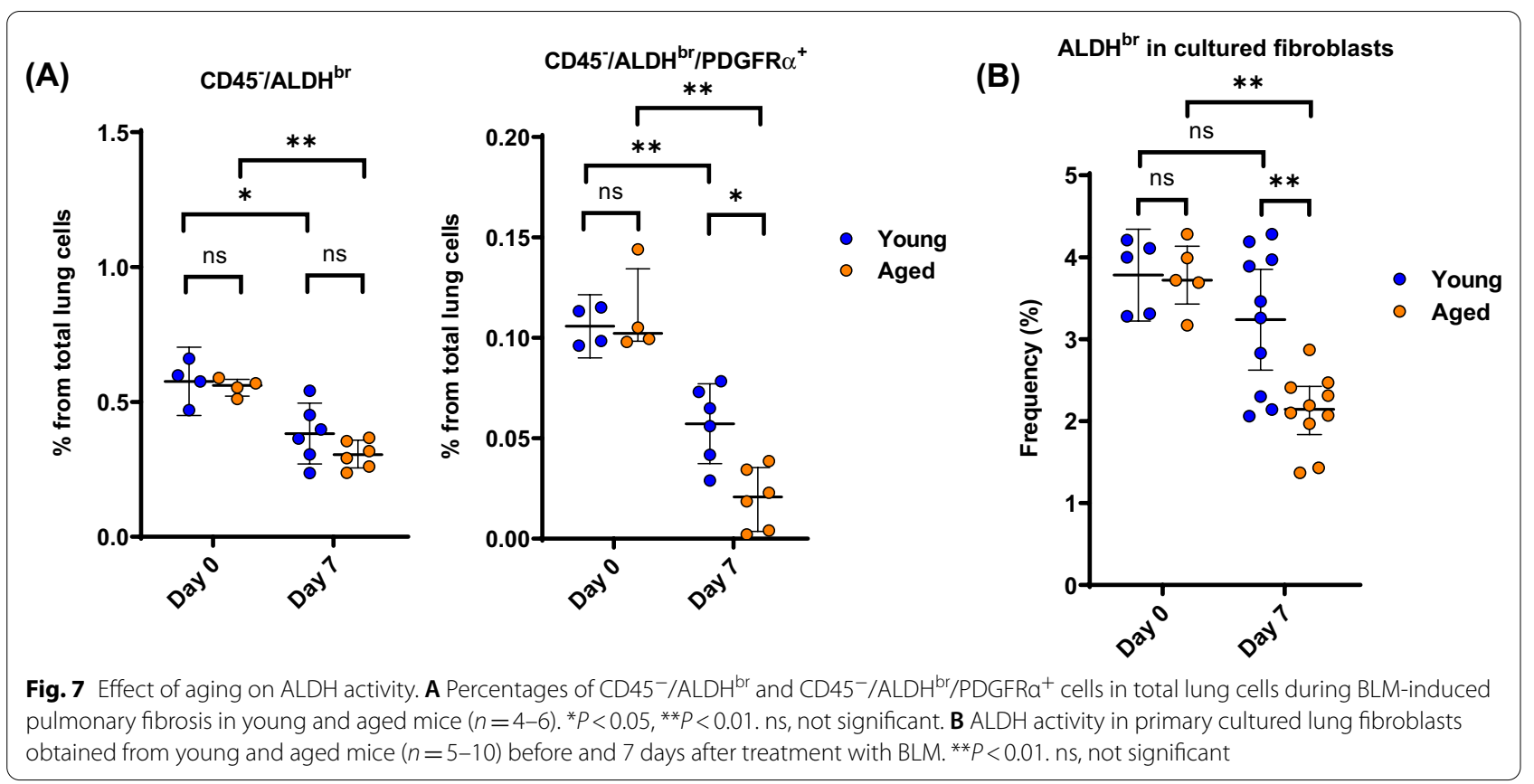

decreased in aged mice $(n=5-10)$ compared with young mice $(n=5-10)$ (Fig. 7B).

\section{Discussion}

The present study identified and characterized the nonhematopoietic/lung resident $\mathrm{ALDH}^{\mathrm{br}}$ cell populations in the mouse lung. The lung $\mathrm{CD} 45^{-} / \mathrm{ALDH}^{\mathrm{br}}$ population and, the $\mathrm{CD} 45^{-} / \mathrm{ALDH}^{\mathrm{br}} / \mathrm{PDGFR}^{+}$subpopulation are cell populations with high proliferative capacity. These population significantly reduced in pulmonary fibrosis. The high levels of expression of ALDH observed in $\mathrm{CD} 45^{-} / \mathrm{ALDH}^{\mathrm{br}}$ cells was mainly attributed to the ALDH1a subfamily, also known as RALDH, which was significantly reduced in BLM-treated lungs. When used as a tool for cell therapy, transferred $\mathrm{CD} 45^{-} / \mathrm{ALDH}^{\text {br }}$ cells reached the site of lung injury and ameliorated BLM-induced pulmonary fibrosis. Thus, this study demonstrated $\mathrm{CD}^{-} 5^{-} / \mathrm{ALDH}^{\mathrm{br}}$ cells as a novel lung-resident stem cell population and suggested their potential therapeutic use in pulmonary fibrosis.

Although ALDH ${ }^{\text {br }}$ cells with stem cell properties have been detected in various normal tissues, including the bone marrow [14, 23], umbilical cord blood [24, 25], mammary glands [26, 27], heart [28], and adipose tissue [29], little is known about lung-resident $\mathrm{ALDH}^{\mathrm{br}}$ cells. A study showed that isolated murine airway basal and submucosal gland duct ALDH ${ }^{\text {br }}$ cells exhibited stem cell properties in normal/healthy lungs [30]. No previous study has investigated the significance of lung-resident $\mathrm{ALDH}^{\mathrm{br}}$ cells in respiratory diseases, such as pulmonary fibrosis. In the current study, lung-resident CD45-/ALD$\mathrm{H}^{\mathrm{br}}$ were rare and heterogeneous population with epithelial and mesenchymal lineages. The percentages of $\mathrm{ALDH}^{\mathrm{br}}$ in both primary cultured lung fibroblasts and fibroblast cell lines were low at approximately $5 \%$, and hence, we assumed that $\mathrm{ALDH}^{\mathrm{br}}$ cells lost their activity during differentiation and proliferation, consistent with the findings of a previous report [24]. Similar to the $\mathrm{CD}^{2} 5^{-} / \mathrm{ALDH}^{\mathrm{br}} / \mathrm{PDGFR}^{+}$population in the current study, CD45 ${ }^{-}$lung SP cells have been reported to express mesenchymal markers and exhibit MSC properties [8], and have been shown to be decreased in BLM-induced pulmonary fibrosis [10]. However, in our study, we found that $\mathrm{CD} 45^{-} / \mathrm{ALDH}^{\mathrm{br}}$ is a novel population that is completely different from lung SP cells $\left(\mathrm{CD} 45^{-} / \mathrm{CD} 31^{-} / \mathrm{Hoe}-\right.$ chst $^{\mathrm{dim}}$ ). Therefore, it is reasonable that the expression of the surface markers of MSCs found in lung $\mathrm{CD} 45^{-} /$ $\mathrm{ALDH}^{\mathrm{br}}$ cells differed from that in the SP cells. Instead, SSEA4, a marker for mesenchymal progenitors [31], was demonstrated to be solely expressed on $\mathrm{CD} 45^{-} / \mathrm{ALDH}^{\text {br }}$ cells in the mouse lung. These results suggest that the $\mathrm{CD} 45^{-} / \mathrm{ALDH}^{\mathrm{br}}$ population might contain mesenchymal progenitors and $\mathrm{CD} 45^{-} / \mathrm{ALDH}^{\mathrm{br}} / \mathrm{PDGFR}^{+}$cells maintained the ability to differentiate into the mesenchymal lineage.

During BLM-induced pulmonary fibrosis, we observed a downregulation in the expression of a broad spectrum of ALDH mRNAs in lung tissues. We also found that transferred $\mathrm{CD} 45^{-} / \mathrm{ALDH}^{\mathrm{br}}$ cells ameliorated BLMinduced pulmonary fibrosis by suppressing IL- 6 and 
TGF- $\beta$. As an evidence, intravenously administered $\mathrm{CD}_{4} 5^{-} / \mathrm{ALDH}^{\mathrm{br}}$ cells were shown to reach the site of lung injury using mCherry-expressing mice as donors. Additionally, these lung-protective effects of transferred $\mathrm{CD}_{4} 5^{-} / \mathrm{ALDH}^{\mathrm{br}}$ were accompanied by a recovery in the levels of ALDH, which had been decreased during fibrosis, suggesting that ALDH was involved in the mechanism of pulmonary fibrosis. Although little is known about the association of ALDH isoforms with lung diseases, ALDH1a1 and ALDH3a1 have been reported to be expressed in the human airway epithelium [32]. Jang and coworkers reported that the expression of ALDH3a1 was markedly increased in human airway epithelial cells exposed to cigarette smoke extract and that ALDH3a1 exerted protective action against smoking-induced airway epithelial damage [33]. In the current study, the expression of both ALDH1a1 and ALDH4a1 were upregulated in $\mathrm{CD}_{4} 5^{-} / \mathrm{ALDH}^{\mathrm{br}}$ cells and downregulated in the fibrotic lung after BLM administration, paralleling the reduction in the number of $\mathrm{CD} 45^{-} / \mathrm{ALDH}^{\mathrm{br}}$ cells. Likewise, intravenous administration of CD45-/ALD$\mathrm{H}^{\text {br }}$ cells was shown to significantly recover the expression of ALDH1a1 and ALDH4a1 in the fibrotic lung. Therefore, we speculated that mesenchymal ALDH1a1 and ALDH4a1 might protect against BLM-induced pulmonary fibrosis. Indeed among ALDH family members, RALDHs (ALDH1a1, ALDH1a2, and ALDH1a3) catalyze the conversion of retinol to ATRA [22], supporting the self-renewal and cell differentiation of stem cells [34]. Several lines of evidence have suggested that ATRA exerted protective action against radiation pneumonitis and BLM-induced lung injury in mice through anti-inflammatory effects by activating protein kinase $C$ $\delta(\mathrm{PKC}-\delta)$, inhibiting mitogen-activated protein kinase P38 $\alpha$ (p38MAPK) and nuclear factor kappa-light-chainenhancer of activated B-cells (NF-kB), and suppressing the production of IL- 6 and TGF- $\beta$ [35-38]. In the current study, we observed the upregulation of retinol-metabolizing pathway molecules, recovery of the expression of RALDH, and suppressed expression of IL- 6 and TGF- $\beta$ in BLM-induced pulmonary fibrosis treated with $\mathrm{CD}_{4} 5^{-}$/ $\mathrm{ALDH}^{\mathrm{br}}$ cell therapy. On the other hand, the significance of ALDH4a1 in lung injury is currently unknown and further investigation is required.

In the fibrotic lung, after BLM administration, we observed a reduction in the number of cells in the CD45-/ALDH ${ }^{\text {br }}$ population, especially of its $\mathrm{CD}^{-} 5^{-} /$ $\mathrm{ALDH}^{\mathrm{br}} / \mathrm{PDGFR}^{+}$subpopulation. This reduction was more remarkably observed in aged mice than in young mice. These results suggested that aging led to a decrease in the number of ALDH ${ }^{\text {br }}$ cells in the lungs, especially in the lung PDGFR $\alpha^{+}$fibroblasts. As fibrotic lung diseases, especially idiopathic pulmonary fibrosis (IPF), commonly

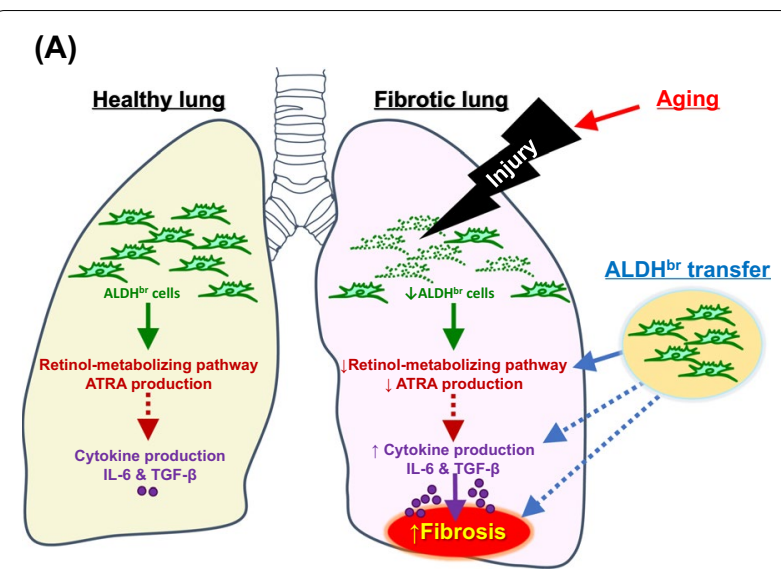

Fig. 8 Summary of the study. Lung injury (e.g., bleomycin-induced lung injury) triggers reduction of ALDH ${ }^{\text {br }}$ cells in the lung, resulting in a suppressed retinol-metabolizing pathway, elevated concentrations of profibrotic cytokines (e.g., IL-6 and TGF $\beta 1$ ), and exacerbation of pulmonary fibrosis. Aging accelerates the injury-induced reduction in $\mathrm{ALDH}^{\mathrm{br}}$ cells. ALDH ${ }^{\mathrm{br}}$ cell therapy restores the impaired antifibrotic effects of ALDH ${ }^{\text {br }}$ cells. Solid and dotted arrows indicate promotion and inhibition, respectively

occur in the elderly [39] and stem cell senescence is one of the suggested causes of IPF [40], it is speculated that the decreased number of ALDH ${ }^{\text {br }}$ cells in the lungs might accelerate fibrotic lung diseases in the elderly.

The limitation of this study is the difficulty in collecting sufficient number of cells. Because of the infrequency of existence of $\mathrm{ALDH}^{\mathrm{br}}$ cells, many donor mice lungs were necessary to acquire a sufficient number of ALDH ${ }^{\text {br }}$ cells, signifying the challenge in applying the methods and the results of the present study to human lung diseases. If the collected cells could be proliferated while maintaining ALDH activity, the burden on donor could be minimized. To apply the current results to human translational studies in the future, development of less invasive methods for collecting ALDH ${ }^{\text {br }}$ cells is required.

\section{Conclusions}

Our results strongly suggest that the lung expression of ALDH and lung-resident $\mathrm{CD} 45^{-} / \mathrm{ALDH}^{\mathrm{br}}$ are involved in pulmonary fibrosis. (Figure 8 summarizes the findings of the current study.) When administered intravenously, $\mathrm{CD} 45^{-} / \mathrm{ALDH}^{\mathrm{br}}$ ameliorated BLM-induced pulmonary fibrosis, signifying the possibility for $\mathrm{CD} 45^{-} / \mathrm{ALDH}^{\mathrm{br}}$ cells to find application as novel and useful cell therapy tools in pulmonary fibrosis treatment.

\section{Abbreviations}

ALDH: Aldehyde dehydrogenase; $\mathrm{ALDH}^{\text {br. }}$ : Cell populations with high ALDH activity; ALDH ${ }^{\text {dim: }}$ : Cell population with low ALDH activity; ATRA: All-trans retinoic acid; BLM: Bleomycin; CRABP: Cellular retinoic acid-binding protein; EpCAM: Epithelial cell adhesion molecule; FACS: Fluorescence activated cell 
sorting; HE: Hematoxylin-eosin; IL: Interleukin; IPF: Idiopathic pulmonary fibrosis; MSCs: Mesenchymal stem cells; NF-kB: Nuclear factor kappa-light-chainenhancer of activated B-cells; PDGFR: Platelet-derived growth factor receptor; PKC- $\delta$ : Protein kinase C $\delta$; p38MAPK: Mitogen-activated protein kinase P38 a; RALDH: Retinal dehydrogenase/retinaldehyde dehydrogenase; RAR: Retinoic acid receptor; SP: Side population; SSEA: Stage-specific embryonic antigen; TGF:Transforming growth factor.

\section{Supplementary Information}

The online version contains supplementary material available at https://doi. org/10.1186/s13287-021-02549-6.

Additional file 1. Antibodies used in flow cytometric experiments.

Additional file 2. Primers used in this study.

Additional file 3. Effect of magnetic-activated cell sorting for the enrichment of $\mathrm{CD}_{4} 5^{-} / \mathrm{ALDH}^{\mathrm{br}}$ cells. Representative image of lung $\mathrm{CD} 45^{-} /$ $\mathrm{ALDH}^{\mathrm{br}}$ cells before and after magnetic-activated cell sorting using the Tissue Stem Cell Pre-Enrichment Kit. ALDH ${ }^{\text {br }}$ gating was determined by comparing samples stained with ALDEFLUOR alone and with ALDEFLUOR and diethylaminobenzaldehyde (DEAB), an ALDH inhibitor.

Additional file 4. Expression of cell surface proteins in $\mathrm{CD} 45^{-} / \mathrm{ALDH}^{\mathrm{dim}}$

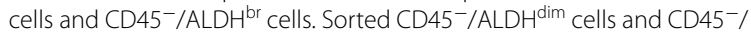
$\mathrm{ALDH}^{\mathrm{br}}$ cells were examined for cell surface markers associated with mesenchymal stem cells (MSCs), fibroblasts, and stem cells.

Additional file 5. ALDH1a1 immunostaining in lung tissue. Representative images of ALDH1a1 immunostaining in PBS- or BLM-treated lung tissue sections on day 14

Additional file 6. Double staining of $\mathrm{ALDH}^{\mathrm{br}}$ cells and side population cells in lung tissue. (A) Representative image of lung CD45 $/$ CD $31^{-} /$ALD- $^{-}$ $\mathrm{H}^{\text {br }}$ live cells. (B) Representative image of lung CD45 $/$ CD31-/Hoechst ${ }^{\text {dim }}$ (side population, SP) live cells. (C) The gating of SP cells was confirmed using verapamil, which is an inhibitor for Hoechst staining. (D) SP cells in lung $\mathrm{CD} 5^{-} / \mathrm{CD} 31^{-} / \mathrm{ALDH}^{\mathrm{br}}$ live cells. (E) ALDH ${ }^{\mathrm{br}}$ cells in SP cells.

Additional file 7. $\mathrm{CD}^{-} 5^{-} / \mathrm{ALDH}{ }^{\text {br }}$ cell therapy ameliorates BLM-induced pulmonary fibrosis. Masson's trichrome staining of lung tissue sections obtained on day 14 from BLM-treated mice transferred with CD45-/ALD$\mathrm{H}^{\text {dim }}$ and $\mathrm{CD}^{-} 5^{-} / \mathrm{ALDH}^{\mathrm{br}}$ cells.

Additional file 8. Discrimination of mCherry-heterozygotic mouse. DNA extracted from the tails of mice was amplified by PCR using primers shown in Table S2. The expression of the mCherry-heterozygotic band was evaluated using agarose gel electrophoresis.

\section{Acknowledgements}

We would like to thank Dr. Kazuo Yamagata (Kindai University) for providing mCherry mice, Yoko Hayashi and Yukari lyanaga for excellent technical assistance, Editage (www.editage.com) for English language editing. A part of this work was carried out at Research Facilities for Laboratory Animal Science, and Natural Science Center for Basic Research and Development, Hiroshima University. This work was supported by the Program of the Network-type Joint Usage/Research Center for Radiation Disaster Medical Science.

\section{Authors' contributions}

HT involved in collection of data, data analysis and interpretation, and manuscript writing. TN involved in conception and design, collection of data, financial support, data analysis and interpretation, and manuscript writing. TM, MN and SS involved in data analysis and interpretation, reviewing the manuscript for important intellectual content and approving for submission. $\mathrm{KY}, \mathrm{YH}, \mathrm{SM}, \mathrm{HI}, \mathrm{KF}$ and $\mathrm{HH}$ involved in reviewing the manuscript for important intellectual content and approving for submission. NH involved in conception and design, financial support, reviewing the manuscript for important intellectual content and approving for submission. All authors have read and approved the manuscript.

\section{Funding}

This work was supported by JSPS KAKENHI (Grand-in-Aid for Scientific Research) Grant Numbers 17 K09654 and 20K08519, and GSK Japan Research Grant 2015. The funders had no role in study design, data collection and analysis, decision to publish, or presentation of the manuscript.

\section{Availability of data and materials}

The data that support the findings of this study are available from the corresponding author upon reasonable request.

\section{Declarations}

\section{Ethics approval and consent to participate}

All experimental procedures were approved by the Institutional Animal Care and Use Committee of Hiroshima University (permit number, A19-122 and 28-29-2).

\section{Consent for publication}

Not applicable.

\section{Competing interests}

The authors declare that they have no competing interests.

\section{Author details}

${ }^{1}$ Department of Molecular and Internal Medicine, Graduate School of Biomedical and Health Sciences, Hiroshima University, 1-2-3 Kasumi, Minami-ku, Hiroshima 734-8551, Japan. ${ }^{2}$ Department of Physical Analysis and Therapeutic Sciences, Graduate School of Biomedical and Health Sciences, Hiroshima University, 1-2-3 Kasumi, Minami-ku, Hiroshima 734-8553, Japan.

Received: 9 May 2021 Accepted: 8 August 2021

Published online: 23 August 2021

\section{References}

1. Wecht S, Rojas M. Mesenchymal stem cells in the treatment of chronic lung disease. Respirology. 2016;21:1366-75. https://doi.org/10.1111/ resp. 12911.

2. Iyer SS, Rojas M. Anti-inflammatory effects of mesenchymal stem cells: novel concept for future therapies. Expert Opin Biol Ther. 2008;8:56981. https://doi.org/10.1517/14712598.8.5.569.

3. Rojas M, Iyer SS, Torres-Gonzalez E, Neujahr DC, Kwon M, Brigham $\mathrm{KL}$, et al. Effect of bone marrow-derived mesenchymal stem cells on endotoxin-induced oxidation of plasma cysteine and glutathione in mice. Stem Cells Int. 2010;2010:868076.

4. Kyurkchiev D. Secretion of immunoregulatory cytokines by mesenchymal stem cells. World J Stem Cells. 2014;6:552.

5. Rojas M, Xu J, Woods CR, Mora AL, Spears W, Roman J, et al. Bone marrow-derived mesenchymal stem cells in repair of the injured lung. Am J Respir Cell Mol Biol. 2005;33:145-52.

6. Hegab AE, Kubo H, Fujino N, Suzuki T, He M, Kato H, et al. Isolation and characterization of murine multipotent lung stem cells. Stem Cells Dev. 2010;19:523-35.

7. Majka SM, Beutz MA, Hagen M, Izzo AA, Voelkel N, Helm KM. Identification of novel resident pulmonary stem cells: form and function of the lung side population. Stem Cells. 2005;23:1073-81.

8. Martin J, Helm K, Ruegg P, Varella-Garcia M, Burnham E, Majka S. Adult lung side population cells have mesenchymal stem cell potential. Cytotherapy. 2008;10:140-51.

9. Summer R, Fitzsimmons K, Dwyer D, Murphy J, Fine A. Isolation of an adult mouse lung mesenchymal progenitor cell population. Am J Respir Cell Mol Biol. 2007;37:152-9.

10. Jun D, Garat C, West J, Thorn N, Chow K, Cleaver T, et al. The pathology of bleomycin-induced fibrosis is associated with loss of resident lung mesenchymal stem cells that regulate effector T-cell proliferation. Stem Cells. 2011;29:725-35.

11. Muzio G, Maggiora M, Paiuzzi E, Oraldi M, Canuto RA. Aldehyde dehydrogenases and cell proliferation. Free Radic Biol Med. 2012;52:735-46. https://doi.org/10.1016/j.freeradbiomed.2011.11.033. 
12. Balber AE. Concise review: aldehyde dehydrogenase bright stem and progenitor cell populations from normal tissues: characteristics, activities, and emerging uses in regenerative medicine. Stem Cells. 2011;29:570-5.

13. Capoccia BJ, Robson DL, Levac KD, Maxwell DJ, Hohm SA, Neelamkavil $\mathrm{MJ}$, et al. Revascularization of ischemic limbs after transplantation of human bone marrow cells with high aldehyde dehydrogenase activity. Blood. 2009;113:5340-51.

14. Gentry T, Foster S, Winstead L, Deibert E, Fiordalisi M, Balber A. Simultaneous isolation of human BM hematopoietic, endothelial and mesenchymal progenitor cells by flow sorting based on aldehyde dehydrogenase activity: implications for cell therapy. Cytotherapy. 2007;9:259-74.

15. Sondergaard CS, Hess DA, Maxwell DJ, Weinheimer C, Rosová I, Creer MH, et al. Human cord blood progenitors with high aldehyde dehydrogenase activity improve vascular density in a model of acute myocardial infarction. J Transl Med. 2010;8:1-13.

16. Nakashima T, Liu T, Hu B, Wu Z, Ullenbruch M, Omori K, et al. Role of $\mathrm{B} 7 \mathrm{H} 3 / \mathrm{IL}-33$ signaling in pulmonary fibrosis-induced profibrogenic alterations in bone marrow. Am J Respir Crit Care Med. 2019;200:1032-44.

17. Ueda J, Maehara K, Mashiko D, Ichinose T, Yao T, Hori M, et al. Heterochromatin dynamics during the differentiation process revealed by the DNA methylation reporter mouse, methylRO. Stem Cell Rep. 2014;2:910-24 https://doi.org/10.1016/j.stemcr.2014.05.008.

18. Alison MR, Guppy NJ, Lim SML, Nicholson LJ. Finding cancer stem cells: are aldehyde dehydrogenases fit for purpose? J Pathol. 2010;222:335-44.

19. Summer R, Kotton DN, Sun X, Ma B, Fitzsimmons K, Fine A. Side population cells and Bcrp1 expression in lung. Am J Physiol Lung Cell Mol Physiol. 2003;285:97-104.

20. Nakashima T, Liu T, Yu H, Ding L, Ullenbruch M, Hu B, et al. Lung bone marrow-derived hematopoietic progenitor cells enhance pulmonary fibrosis. Am J Respir Crit Care Med. 2013;188:976-84.

21. Sisson TH, Hanson KE, Subbotina N, Patwardhan A, Hattori N, Simon $\mathrm{RH}$. Inducible lung-specific urokinase expression reduces fibrosis and mortality after lung injury in mice. Am J Physiol Lung Cell Mol Physiol. 2002;283:1023-32.

22. Ma I, Allan AL. The role of human aldehyde dehydrogenase in normal and cancer stem cells. Stem Cell Rev. 2011;7:292-306.

23. Armstrong L, Stojkovic M, Dimmick I, Ahmad S, Stojkovic P, Hole N, et al. Phenotypic characterization of murine primitive hematopoietic progenitor cells isolated on basis of aldehyde dehydrogenase activity. Stem Cells. 2004;22:1142-51.

24. Seneviratne AK, Bell GI, Sherman SE, Cooper TT, Putman DM, Hess DA. Expanded hematopoietic progenitor cells reselected for high aldehyde dehydrogenase activity demonstrate islet regenerative functions. Stem Cells. 2016;34:873-87.

25. Nagano M, Yamashita T, Hamada H, Ohneda K, Kimura Kl, Nakagawa T, et al. Identification of functional endothelial progenitor cells suitable for the treatment of ischemic tissue using human umbilical cord blood. Blood. 2007;1 10:151-60.

26. Ginestier C, Hur MH, Charafe-Jauffret E, Monville F, Dutcher J, Brown M, et al. ALDH1 is a marker of normal and malignant human mammary stem cells and a predictor of poor clinical outcome. Cell Stem Cell. 2007; 1:555-67.

27. Douville J, Beaulieu R, Balicki D. ALDH1 as a functional marker of cancer stem and progenitor cells. Stem Cells Dev. 2009;18:17-25.

28. Roehrich ME, Spicher A, Milano G, Vassalli G. Characterization of cardiacresident progenitor cells expressing high aldehyde dehydrogenase activity. Biomed Res Int. 2013;2013:503047.

29. Itoh H. Aldehyde dehydrogenase activity helps identify a subpopulation of murine adipose-derived stem cells with enhanced adipogenic and osteogenic differentiation potential. World J Stem Cells. 2017;9:179-86.

30. Hegab AE, Ha VL, Darmawan DO, Gilbert JL, Ooi AT, Attiga YS, et al. Isolation and in vitro characterization of basal and submucosal gland duct stem/progenitor cells from human proximal airways. Stem Cells Transl Med. 2012;1:719-24.

31. Xia H, Bodempudi V, Benyumov A, Hergert P, Tank D, Herrera J, et al. Identification of a cell-of-origin for fibroblasts comprising the fibrotic reticulum in idiopathic pulmonary fibrosis. Am J Pathol. 2014;184:136983. https://doi.org/10.1016/j.ajpath.2014.01.012.

32. Patel M, Lu L, Zander DS, Sreerama L, Coco D, Moreb JS. ALDH1A1 and ALDH3A1 expression in lung cancers: correlation with histologic type and potential precursors. Lung Cancer Irel. 2008;59:340-9.

33. Jang JH, Bruse S, Liu Y, Duffy V, Zhang C, Oyamada N, et al. Aldehyde dehydrogenase $3 \mathrm{~A} 1$ protects airway epithelial cells from cigarette smoke-induced DNA damage and cytotoxicity. Free Radic Biol Med. 2014;68:80-6. https://doi.org/10.1016/j.freeradbiomed.2013.11.028.

34. Khillan JS. Vitamin A/retinol and maintenance of pluripotency of stem cells. Nutrients. 2014;6:1209-22.

35. Tabata C, Kadokawa Y, Tabata R, Takahashi M, Okoshi K, Sakai Y, et al. Alltrans-retinoic acid prevents radiation- or bleomycin-induced pulmonary fibrosis. Am J Respir Crit Care Med. 2006;174:1352-60.

36. Dong Z, Tai W, Yang Y, Zhang T, Li Y, Chai Y, et al. The role of all-trans retinoic acid in bleomycin-induced pulmonary fibrosis in mice. Exp Lung Res. 2012;38:82-9.

37. Song X, Liu W, Xie S, Wang M, Cao G, Mao C, et al. All-transretinoic acid ameliorates bleomycin-induced lung fibrosis by downregulating the TGF$\beta 1 /$ Smad3 signaling pathway in rats. Lab Investig. 2013;93:1219-31.

38. Leem AY, Shin MH, Douglas IS, Song JH, Chung KS, Kim EY, et al. All-trans retinoic acid attenuates bleomycin-induced pulmonary fibrosis via downregulating EphA2-EphrinA1 signaling. Biochem Biophys Res Commun. 2017;491:721-6. https://doi.org/10.1016/j.bbrc.2017.07.122.

39. Wijsenbeek M, Cottin V. Spectrum of fibrotic lung diseases. N Engl J Med. 2020;383:958-68

40. Aldera JK, Barkauskas CE, Limjunyawong N, Stanley SE, Kembou F, Tuder RM, et al. Telomere dysfunction causes alveolar stem cell failure. Proc Natl Acad Sci USA. 2015;112:5099-104.

\section{Publisher's Note}

Springer Nature remains neutral with regard to jurisdictional claims in published maps and institutional affiliations.
Ready to submit your research? Choose BMC and benefit from:

- fast, convenient online submission

- thorough peer review by experienced researchers in your field

- rapid publication on acceptance

- support for research data, including large and complex data types

- gold Open Access which fosters wider collaboration and increased citations

- maximum visibility for your research: over $100 \mathrm{M}$ website views per year

At BMC, research is always in progress.

Learn more biomedcentral.com/submissions 